\title{
Selection and Justification of a Digital System Broadcasting for the Republic of Angola
}

\author{
V.M.J. Santos ${ }^{1,2 *}$ \\ ${ }^{1}$ Ministry of Telecommunications, Information Technology and Social Communication \\ ${ }^{2}$ Lusiada University of Angola \\ Luanda, Angola \\ *Адрес для переписки: svirgilio5@gmail.com
}

\section{Article info}

DOI:10.31854/1813-324X-2021-7-3-55-63

Received 16th July 2021

Accepted 22nd July 2021

For citation: Santos V.M.J. Selection and Justification of a Digital System Broadcasting for the Republic of Angola. Proc. of Telecom. Universities. 2021;7(3):55-63. (in Russ.) DOI:10.31854/1813-324X-2021-7-3-55-63

\begin{abstract}
In this work we seek to approach the choice of the Republic of Angola for the ISDB-T telebroadcasting system. The experimental results of the ISDB-T digital transmission system in the Republic of Angola are Execelente. Currently, the Japanese terrestrial digital broadcasting system (ISDB-T) is used in 14 countries around the world (Argentina, Bolivia, Brazil, Chile, Costa Rica, Japan, Peru, Paraguay, El Salvador, Uruguay, Honduras, Venezuela, Philippines, Botswana) and 6 more countries (Angola, Maldives, Sri Lanka, Guatemala, Ecuador, Nicaragua) have adopted this system. The study shows that ISDB-T is a system applicable in our country, as even with the transmitter operating at 50\% of its maximum power, the signal is received in a large part of the city of Luanda, with failures only in regions far from the center urban. The implementation of a fully digital transmitter that is foreseen, the increase of the transmitter's power, among other changes, may provide better advantages in implementing the ISDB$T$ in the Republic of Angola. The commitment comes at a time when Angola plans to cover the entire national territory, starting in 2023.
\end{abstract}

Keywords: transmission, digital, frequency, ISDB-T, system, broadcaster, television, Angolan public television.

\section{INTRODUCTON}

There are a large number of digital broadcasting standards in the world today. The recommendations of the International Telecommunications Union BT.1368-13(6/2017), [1, 2, 3, 4] BS.111-6 and BS.1660-(08/2019) present the design characteristics, technical characteristics and network planning of the following transmission systems digital terrestrial broadcasting:

- DVB, known as a European standard for digital TV, it was designed in the 1980s by the consortium, which today has 250 members from 15 countries;

- T-DAB, 174-230 MHz frequency band allocated to it, VHF III;

- ISDB-TSB, on television channels with a width of 6, 7 or $8 \mathrm{MHz}$ for broadcasting broadcast programs, a segment is allocated as one-fourth of the frequency band of a television channel, the frequency band of this segment is of $429 \mathrm{kHz}(06 / 14), 500(07 / 14), 571$ (08/14); however, this bandwidth must still be selected taking into account the frequency situation in each country;
- DRM (Digital Radio Mondiale), recommended for use in the LF bands $(30-300 \mathrm{kHz})$ in the frequency band 0,1485-0,2855 MHz (long waves, LW), MF (300$3000 \mathrm{kHz}$ ) in the frequency bands $0,5265-1,6065 \mathrm{MHz}$ (middle waves, MW) and $\mathrm{HF}$ (3-30 MHz). Remember that in the HF band in its different parts for transmission, the frequency bands 3,2-3,640, 4,75-4,995, $5,006-5,06,5,95-6,2,7,10-7,30,9,50-9,90,11,65-$ $12,05,13,6-13,8,15,10-15,60,17,55-17,90,21,45-21$, 85, 25,67-26,10 MHz (short wave, HF);

- DRM + $[2,3,4,12]$ (is an extension of the DRM standard), recommended for use in the VHF band (30$300 \mathrm{MHz}$ ) in the frequency bands allocated for transmission to mobile and fixed reception (VHF I 65,9-74 MHz, VHF II (87,5-108 MHz), VHF III (174-230 MHz);

- IBOC HD Radio FM, recommended for VHF applications;

- IBOC HD Radio AM [2, 13, 15], recommended for use in the LF, MF, HF bands;

- RAVIS $[2,3,14,15]$, a real-time audiovisual home information system is recommended by the ITU-R for use in the VHF band.

- the ISDB (Integrated Services Digital Broadcasting) system was developed in Japan by the DIBEG 
(Digital Broadcasting Experts Groups) consortium with the support of the NHK. Broadcaster the is pointed out by he researchers as the most flexible standard for presenting better answers to mobility and portability needs.

ISDB is an integrated system consisting of three types of services: satellite transmission (ISDB-S), cable transmission (ISDB-C) and terrestrial transmission (ISDB-T). The ISDB terrestrial broadcasting service, in addition to having a version for digital television broadcasting, also features a version for digital audio broadcasting, the Integrated Services Digital Broadcasting - Terrestrial Sound Broadcasting, ISDB-Tsb.

In figure 1, we describe the entire ISDB-T system. The transmission system, BST-OFDM, sets up a transmission band composed of OFDM segments, each with a bandwidth of $6 / 14 \mathrm{MHz}$. The transmission parameters can be adjusted individually for each segment, making the channel composition flexible.

In addition, to interface between multiple MPEG-2 transport streams (TSs) and the BST-OFDM (BandSegmented Transmission Orthogonal Frequency Division Multiplexing) transmission system, these TSs are re-multiplexed into a single TS. In addition, transmission control information, such as channel segment configuration, transmission parameters, etc., is sent to the receiver in the form of a transmission configuration multiplexing (TMCC) control signal $[7,16]$.

The ISDB-T system features three transmission modes with different carrier intervals to handle a variety of conditions, such as variable guard interval as determined by network configuration and Doppler shift occurring in mobile reception. Table 1 shows us the basic parameters of each mode.

In fact, an OFDM segment corresponds to a frequency spectrum with a bandwidth of $6 / 14 \mathrm{MHz}$ (about $430 \mathrm{kHz}$ ). In Mode 1, a segment consists of 108 carriers, while Modes 2 and 3 have twice and four times that number of carriers, respectively. Broadcasting and television broadcasting employs 13 segments with a transmission bandwidth of about 5,6 MHz. Terrestrial digital audio transmission, on the other hand, uses one or three segments.
A digital signal is transmitted in symbol sets. A symbol consists of $2 \mathrm{~b}$ in QPSK and DQPSK, $4 \mathrm{~b}$ in 16QAM, and 6b in 64QAM. Here, the effective length of the symbol is the reciprocal of the carrier interval this is the condition that prevents carriers in the band from interfering with each other. The guard interval is a time-redundant information section that adds a copy of the last part of a symbol to the symbol's "front porch" in order to absorb interference from multipath delayed waves. Consequently, increasing the guard interval ratio in the signal decreases the information bit rate [7].

TABLE 1. Transmission Parameters for ISDB-T $[7,9,10,16]$

\begin{tabular}{|c|c|c|c|}
\hline Transmission Parameter & Mode 1 & Mode 2 & Mode 3 \\
\hline No. of OFDM Segments & \multicolumn{3}{|c|}{13} \\
\hline Bandwidth, MHz & 5,575 & 5,573 & 5,572 \\
\hline Carrier Interval, kHz & 3,968 & 1,984 & 0,992 \\
\hline № of Carries & 1405 & 2809 & 5617 \\
\hline Carrier Modulation & \multicolumn{3}{|c|}{ QPSK, 16QAM, 64QAM, DQPSK } \\
\hline $\begin{array}{l}\text { Effective Symbol Length } \\
\text { (Tu), } \mu \mathrm{s}\end{array}$ & $252 \mu \mathrm{s}$ & $504 \mu \mathrm{s}$ & $1,008 \mathrm{~ms}$ \\
\hline $\begin{array}{l}\text { Guard-Interval } \\
\text { Length (Tg) } \\
\end{array}$ & \multicolumn{3}{|c|}{$\begin{array}{c}1 / 4,1 / 8,1 / 16,1 / 32 \\
\text { of Effective Symbol Length }\end{array}$} \\
\hline № of Symbols per Frame & \multicolumn{3}{|c|}{204} \\
\hline Time Interleave & \multicolumn{3}{|c|}{ Maximum 4 values: $0,0,1,0,2,0,4 \mathrm{sec}$} \\
\hline Frequency Interleave & \multicolumn{3}{|c|}{$\begin{array}{c}\text { Intra-Segment } \\
\text { and Inter-Segment Interleaving }\end{array}$} \\
\hline Inner Code & \multicolumn{3}{|c|}{$\begin{array}{l}\text { Convolutional coding }(1 / 2,2 / 3,3 / 4 \text {, } \\
5 / 6,7 / 8)\end{array}$} \\
\hline Outer Code & \multicolumn{3}{|c|}{ RS $(204,188)$} \\
\hline Information Bit Rate, Mbps & \multicolumn{3}{|c|}{$3,65-23,23$} \\
\hline Hierarchical Transmission & \multicolumn{3}{|c|}{$\begin{array}{l}\text { Maximum } 3 \text { Levels } \\
\text { (Layer } A, B \text {, and } C \text { ) }\end{array}$} \\
\hline
\end{tabular}

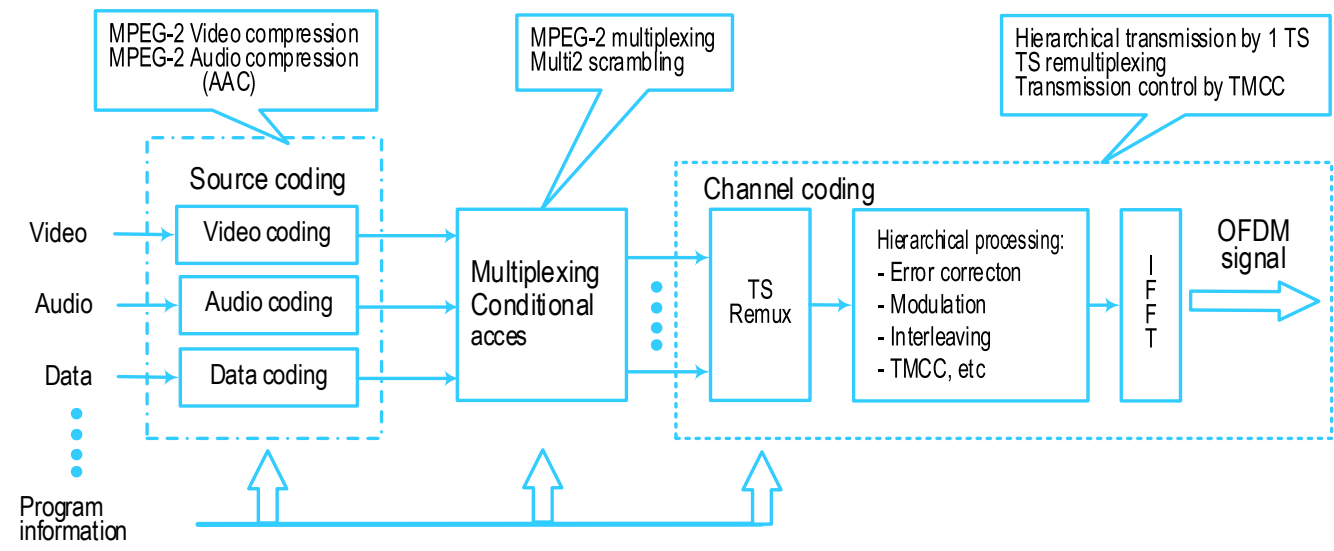

Fig. 1. ISDB-T System Configuration 
We will now see that an OFDM frame consists of 204 symbols with guard intervals attached regardless of transmission mode. The duration of the real-time interleaving depends on the parameters set in the digital signal stage and the duration of the guard interval, and the values shown in table 1 for this parameter are therefore approximate values.

Error correction schemes are concatenated codes, namely, Reed - Solomon $(204,188)$ code for the external code and a convolutional code for the internal code. The information bit rate takes on various values depending on the selected modulation scheme, the internal code coding rate and the guard interval ratio. The range shown in the table reflects the minimum and maximum values for 13 segments $[1,5,6]$.

\section{ANGOLA CHOSEN THE ISDB-T BROADCASTING SYSTEM}

In 2019 Angola signed a two-year agreement with the Republic of Japan, which consists of the development of the master plan including a timetable for migration to new services such as multimedia transmission, acquisition of transmission equipment, among other services.

Under the agreement, the Japanese party guarantees technical support, training of staff inside and out- side the country, in addition to technological equipment for the implementation of the process in Angola.

The compromise comes at a time when Angola plans to have coverage throughout the national territory, from 2023 onwards. Digital terrestrial television is part of the modernization of the telecommunications sector, information and social communication technologies in Angola.

In a first phase, it is foreseen the application of 320 thousand Euros per year in the pilot project underway in the provinces of Luanda, Malanje and Cabinda. The purpose of the agreement, the Minister of Telecommunications, Information Technologies and Social Communication Manuel Homem, said that with DTT (Digital Terrestrial Television) the country will be able to transmit content related to the implementation of the distance education program [8].

Currently, the Japanese terrestrial digital broadcasting system is used in 14 countries around the world (Argentina, Bolivia, Brazil, Chile, Costa Rica, Japan, Peru, Paraguay, El Salvador, Uruguay, Honduras, Venezuela, Philippines, Botswana) and 6 more countries (Angola, Maldives, Sri Lanka, Guatemala, Ecuador, Nicaragua) have adopted this system. In figure 2, we show the countries in the world using the ISDB-T system.

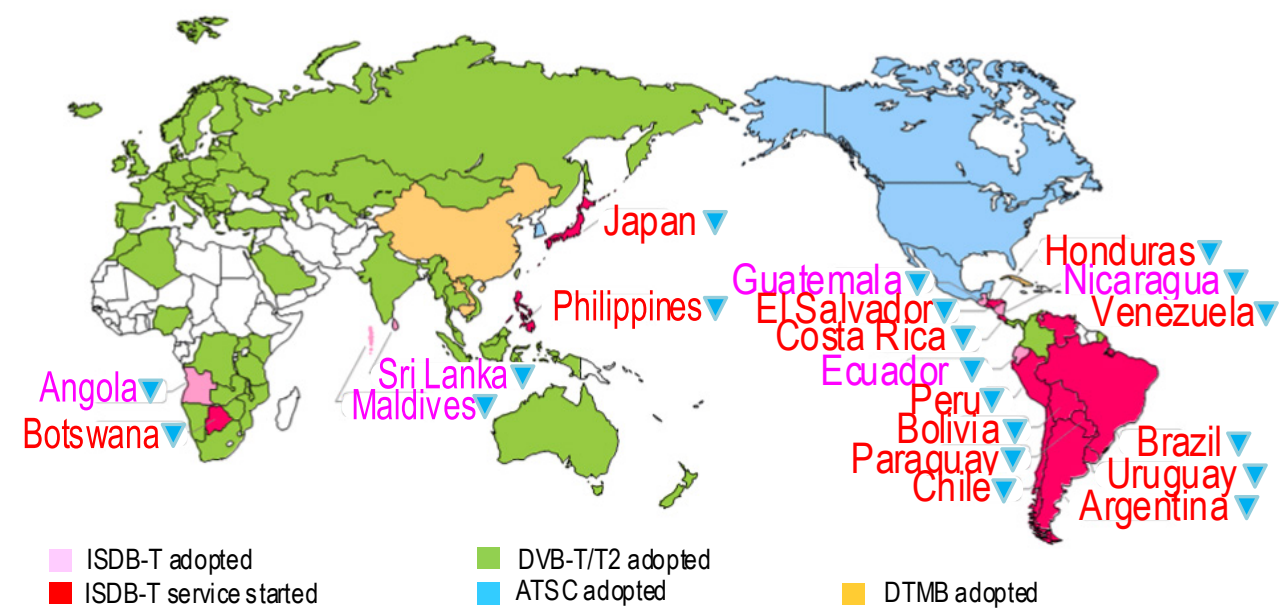

Fig. 2. Countries in the World Using the ISDB-T System

\section{IMPLEMENTATION STUDY OF DIGITAL TERRESTRIAL TELEVISION IN ANGOLA}

The practical work was carried out in partnership with TPA (Public Television of Angola) technicians, in the transmission Center of Viana and in the transmission center of the Palace of Justice (in the upper city, in Luanda). At the Viana Transmitter Center, the study of analogue terrestrial television transmission was carried out as a basis for the knowledge of digital television transmission. At the Palace of Justice, it was possible to carry out part of the work corresponding to the study of the implementation of digital television in Angola, as well as the study of the signal quality of the
ISDB-T system that is currently being tested in the city, from Luanda, Malanje and Cabinda.

\subsection{STUDY OF ANALOGUE TELEVISION IN ANGOLA}

In Angola, the PAL system (for analogue television), standard I, is currently used with the following characteristics: 625 lines, $50 \mathrm{~Hz}$ frame frequency, with 25 frames per second, with $8 \mathrm{MHZ}$ channels, with negative AM-VSB modulation.

For transmitter, analog transmitters from a Spanish company BTESA are used, under the supervision of national technicians. TPA has several broadcasting centers spread over several parts of the country and each one of them operates in a specific channel in the VHF or 
UHF bands. In Luanda there are three Transmission Centers for analogue broadcasting (in Viana, in Prenda - Lote 22 and in the upper city - Palace of Justice) of which one also operates with digital broadcasts (Palace of Justice). The signal is generated and edited in TPA's studios (near the Ministries) and after it is ready for broadcast, it is transmitted by microwave and via satellite, simultaneously, to the transmitting centers. The issue in two media is due to the possibility of failure in one of them. At the transmitter center, the received signal is monitored and sent to the transmitter (composed of image processor, audio and video modulator, up-converter, pre-amplifier and Study of the implementation of Digital Television at TPA (Luanda - Angola), In figure 3, we show the power amplifier which after signal adequacy sends the signal from the antenna that radiates it into space $[9,10]$.

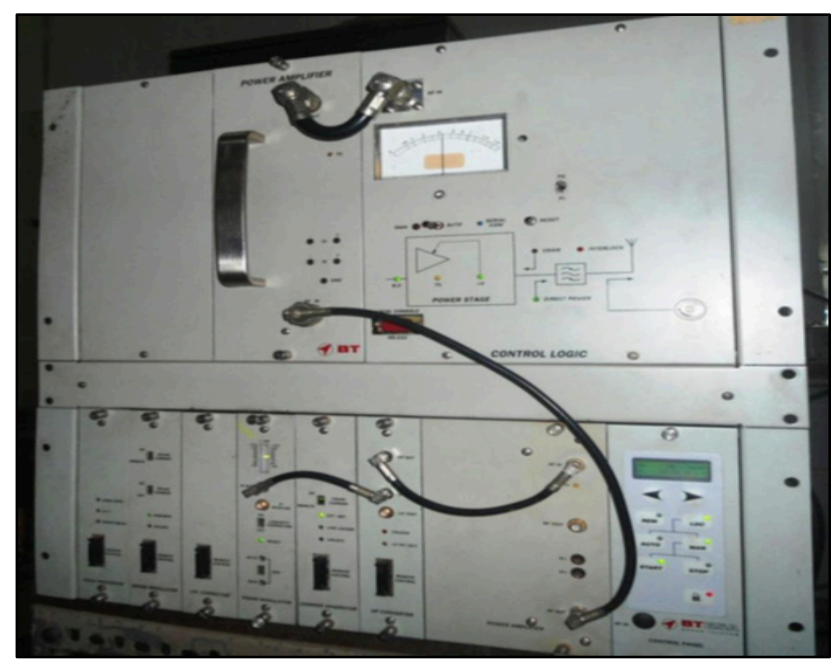

Fig. 3. The power amplifier in Angola Public Television Broadcaster (TPA)

Due to the curvature of the earth, the television signal has a range limitation, so there must be several transmitter centers or several repeaters to cover a larger area. TPA, covering the province of Luanda, has three issuing centers (Viana, Prenda and Palace of Justice - High City).

To carry out the study of the operation of the transmitter, the GST (Test Signal Generator), Audio Generator, BTESA Analog Television Transmitter, fictitious antenna, oscilloscope and receiver (television) were used.

The Test Signal Generator replaces the real source of the image (in this case the camera), generating a test image (at our choice). Audio signal is obtained from the audio generator. The two signals are injected into the transmitter where the basic parameters are set. This signal is emitted by a dummy antenna (which emits in a very short space, about 10 to 15 meters). Through the receiver (television) we can check if the emitter is working correctly or not.

The oscilloscope is used to check the electrical signal (composite video signal) that is generated by the GST and the various parameters of the same signal, such as carrier, envelope, period of each line, line frequency, etc. Based on this experiment, it allowed us to study the operation of analogue television in Angola. In figure 4, show Image Generated by GST (left) and Electrical Signal of Two Lines of it, Seen in Oscilloscope (Right, Below).

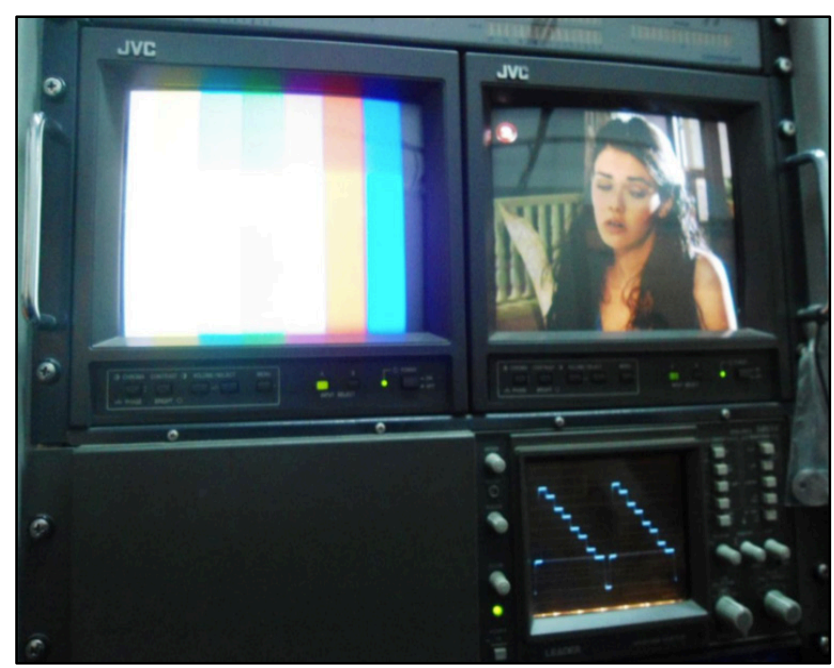

Fig. 4. Image Generated by GST (left) and Electrical Signal of Two Lines of it, Seen in Oscilloscope (Right, Below)

\subsection{IMPLEMENTATION OF THE ISDB-T SYSTEM IN ANGOLA ADAPTED TO AN 8 MHZ BAND}

At the regional conference of the International Telecommunication Union held in Geneva in 2006, June 2015 was set as the official date for the end of the broadcast of Analog Television. At the SADC (Southern African Development Community) level, 2013 and 2014 were envisaged as a preparatory phase for migration.

The transition from analogue to digital television systems, established by the ITU-R Regional Radio Communications Conference in Geneva in 2006 (RRC06), was to be completed in June $2015[5,6]$. However, due to various reasons (organizational, economic, technical and pandemic), this period was later postponed to 2020 [9]. At the level of the Southern African Development Community (SADC) 2013 and 2014 were envisaged as a preparatory phase for migration.

After 11 years, tests for digitization in Angola were restarted, with a group of technicians from the Ministry of Telecommunications, Information Technologies and Social Communication (MINTTICS) in cooperation with a group of Japanese technicians, at the time to study of the implementation of the ISDB-T System with the changes made by the Brazilians, adapted for a band of $8 \mathrm{MHz}$. The tests were carried out first for a band of $6 \mathrm{MHz}[8,9]$.

Currently, the ISDB-T (Japanese) system is being tested, adapted for an $8 \mathrm{MHz}$ band, working only with the broadcast of Channel 1 Public Television of Angola 1 (TPA 1) in SD (Standard Definition), a test broadcast in HD and emission of channel 1 in LD (low definition, for mobile reception). 
The ISDB-T transmission that is being used in the transmitter center is represented in the following figure 5, composed by: GPS Locator (Epsilon Clock 22 Serie), Multi-tiplexer (NEC MX-1500), Encoders and decoders (NEC VC-710 audio, and NEC MF712/NOIF video, VD-7300 and VC-7301), BlackBox - SD/HD/LD Converter (EDIROL VC-300HD) and Exciter or Modulator (NEC DM-300).

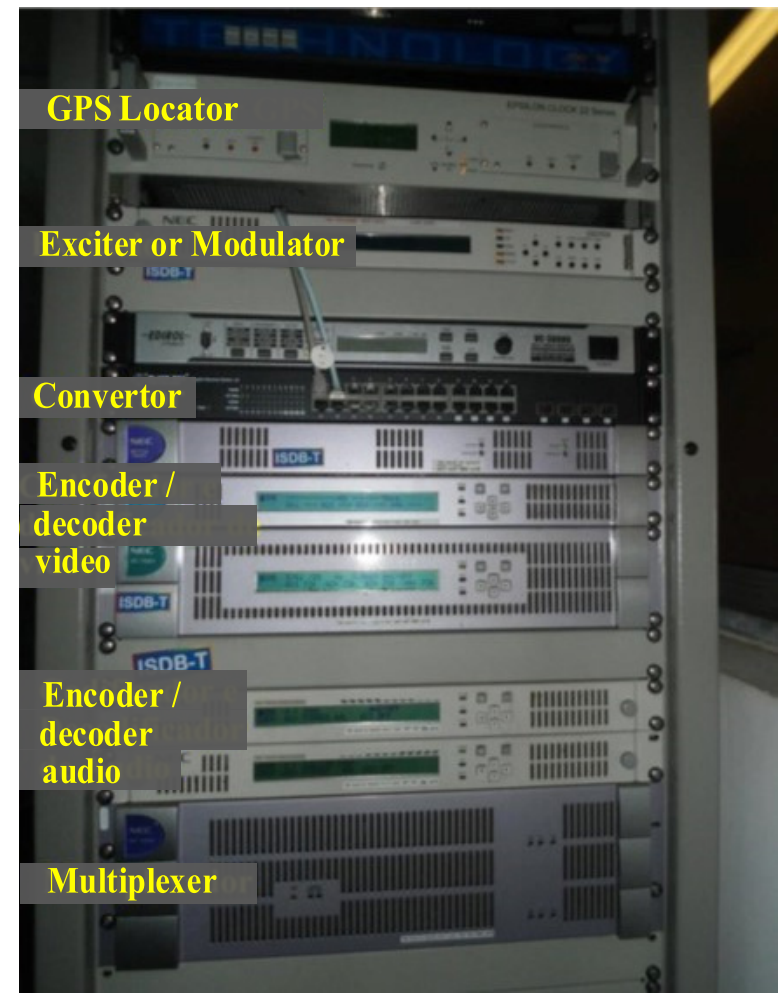

Fig. 5. Adapted Digital Broadcaster in Use in Public Television of Angola

This digital transmission is adapted to an analog amplifier which in turn is connected to the radiant system. In figure 6, show the connecting the Digital Transmitter to the Analogue Amplifier.

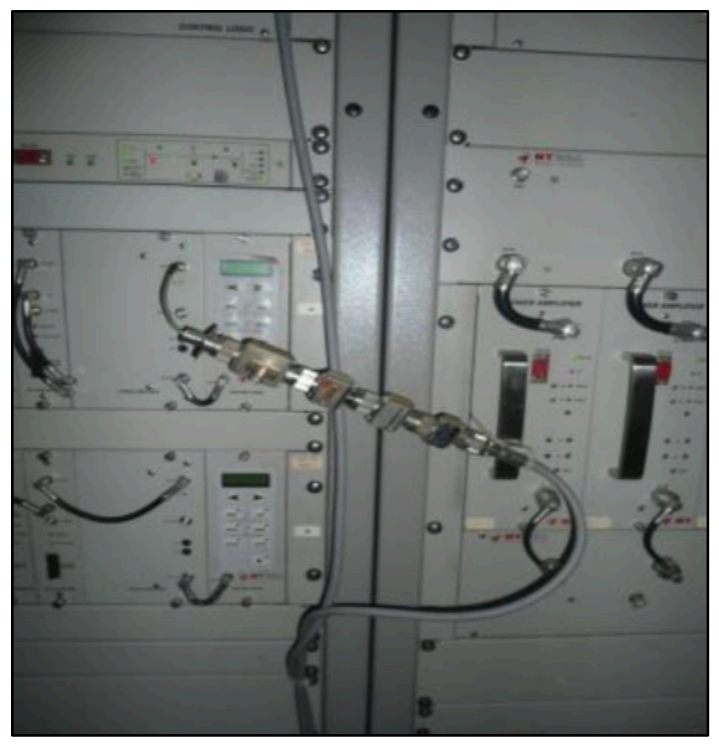

Fig. 6. Connecting the Digital Transmitter to the Analogue Amplifier
In addition, a multiplexer block is connected to a computer that has appropriate software to send interactivity information (News, Weather, E-Gov, etc.).

Any citizen with a receiver suitable for the ISDB-T system can now access Digital TV content from a television or via mobile phone. But it is not advisable to replace analogue devices because there is still no definition on which digital television system will be adopted in Angola, although there is a high probability of adoption of the ISDB.

In cell phone reception, in addition to the television images, the receiver (user) also has the possibility of accessing a set of data, such as: News, Weather, E-Gov, E-Hosp., E-Ed, which they are internet pages with some information of collective interest. For now, these pages are also just test pages that are issued by a computer that is connected to the digital sender.

A very important innovation of ISDB is the Channel segmentation. In analogue broadcasts, a transmitter is required to transmit the information of each program. Therefore, to broadcast the contents of TPA 1 and TPA 2 , two broadcasters are needed in each broadcasting center. In digital television, fundamentally in ISDB, as it is possible in a width of $8 \mathrm{MHz}$ to transmit several programs simultaneously, so each channel is divided into several segments, each one destined to transmit one or a part of a program. Usually, the channel is divided into 13 segments, and the broadcasts of TPA1 in SD, Test Channel in HD and TPA1 in LD are made from the same transmitter [12].

Another innovation in digital television in Angola is the MPEG-4 compressor. The test broadcast no longer uses the traditional MPEG-2, which appears in the theoretical description of the systems. In this broadcast, compression is done by MPEG-4, which has a higher quality than MPEG-2 and a relatively lower compression rate, but suitable for television broadcasts.

The digital terrestrial television broadcast in Luanda is already on the air, in an experimental phase, on channel 31. The difference in image quality between analogue and digital transmission can go unnoticed for a superficial observation. In figure 7 , show Image of analogue (left) and Digital (Right)

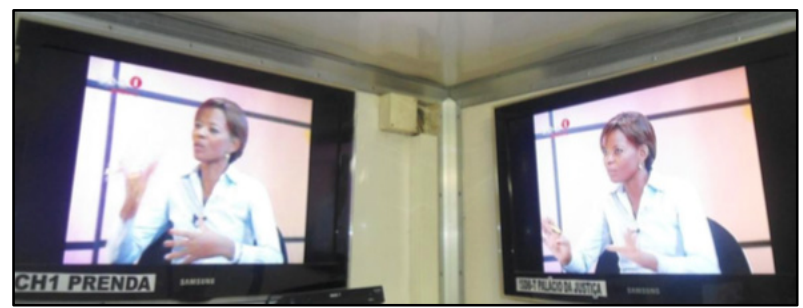

Fig. 7. Image of Analogue Broadcast (Left) and Digital Broadcast (Right)

More on receivers with larger screens or even with a closer look it is possible to notice the differences. In figure 8, show the differences Image of analogue (left) and Digital (Right) 


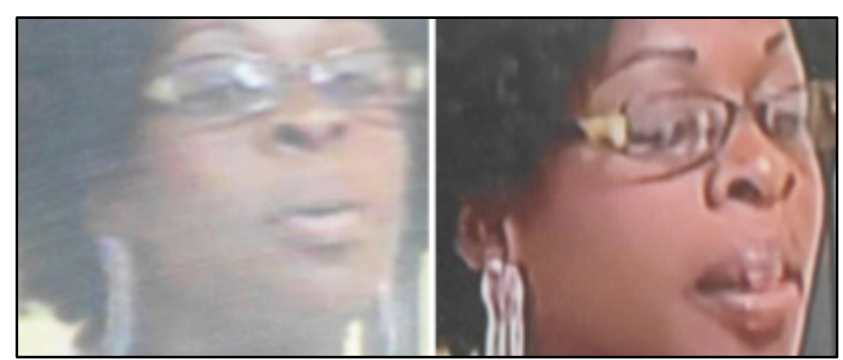

Fig. 8. Image of Analogue Broadcast $[11,12]$ (Left) and Digital Broadcast (Right)

\section{SIGNAL QUALITY OF THE EXPERIMENTAL DIGITAL TV BROADCASTER IN LUANDA}

The objective of the study was to verify the quality of the signal transmitted by the experimental digital television transmitter located at the Center for Transmission of the Palace of Justice. The work was based on traveling around the city, and at various points, strategically defined, stopping and checking the quality of reception of the digital signal at that point. The team was accompanied by a system for fixed reception, consisting of a radio frequency reception antenna (Yagi antenna, in common use), a set-top-box, a television, an NTT how mobile phone (with capacity to receive the ISDB-T), GPS Receiver and Spectrum Analyzer [7, 9]. In figure 9, show the electric field strength as a function of distance from the transmitter. In the figure 10, we show the TPA signal reception from a Mobile Phone.

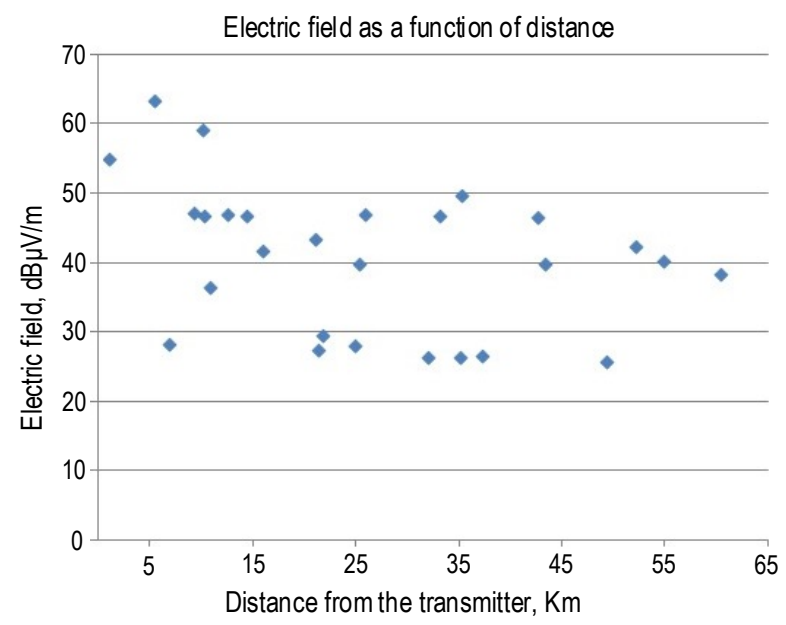

Fig. 9. Electric Field Strength as a Function of Distance from the transmitter

In each of the chosen locations, the system for fixed reception is set up (Television, antenna and set-topbox) and the two receivers are connected (Television and Mobile). With them, quality is observed. Good quality was considered for the areas where images are received without flaws. The areas where the signal with pixelation is received (images with macroblocks, microblocks or distorted pixels) were considered as poor quality.

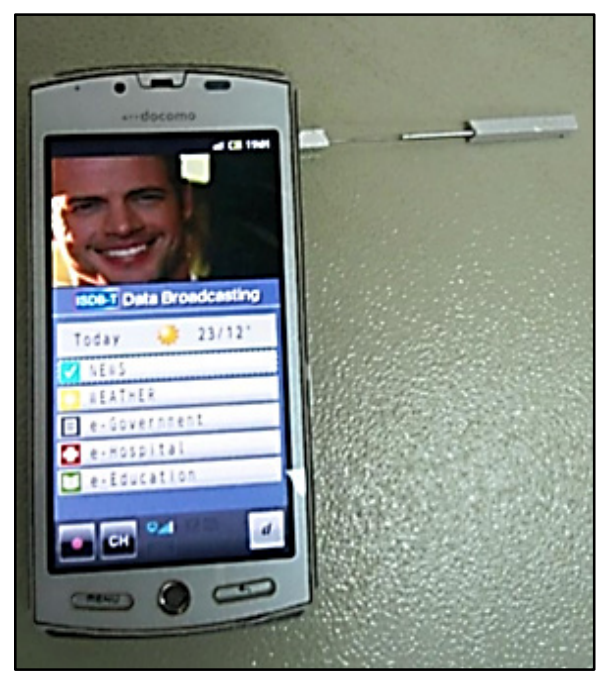

Fig. 10. TPA Signal Reception from a Mobile Phone

With the GPS receiver, we found the geographic coordinates of the place where we were and from there, introducing the coordinates of the transmitter (identified in the table by TX), we determined the distance between the transmitter and the point under study. We measured, through the spectrum analyzer, the intensity of the electric field at these points and analyzed the quality of reception from a television and from a mobile phone. The results of this field study are presented in the table below. We can relate the electric field strength to the distance from the following graph.

The theory leads us to the idea that signal strength depends on distance.

And this is true, and we observe in the graph, because for points farther away from the transmitter, a weaker signal is observed. But, with this work we can also prove that the range of the television signal, digital in this case, does not depend solely on distance. It also depends a lot on some aspects related to the issuer itself. It was observed that for reception with fixed TV, at the highest points, with an altitude of around $140 \mathrm{~m}$, the signal reception presents good quality in a radius of 20 $\mathrm{km}$ with a field strength of about $27 \mathrm{~dB} \mu \mathrm{V} / \mathrm{m}$ and at points with altitude $100 \mathrm{~m}$ reception is good in a radius of approximately $35 \mathrm{~km}$ with a field strength of about $39 \mathrm{~dB} \mu \mathrm{V} / \mathrm{m}$. As for mobile reception, these radii are relatively small. For exemples are the areas avenue of LAC, SHOPRITE, Comarca, Viana, Morro, Luz, Futungo the Belas, Praça do Benfica, Santoiro, Vidrul, Vila do Cacuaco, Panguila, etc. At distances greater than these, the field strength is less and the signal quality is poor. Examples are the following areas: Bar of Dande, Porto Kipiri, Bar of Kwanza, Ramiros, Zango 4, Km 30 (catete road), etc. In the table 2 show ISDB-T signal quality study in Luanda.

It was noticed a lot of difficulty in receiving the signal at very high points, which, from now on, raises the hypothesis that the location of the emitter and the radiation diagram of the transmitting antenna have an influence on the results. 
TABLE 2. ISDB-T Signal Quality Study in Luanda

\begin{tabular}{|c|c|c|c|c|c|c|c|c|c|c|}
\hline \multirow{2}{*}{$\mathrm{N}$} & \multirow{2}{*}{ Data } & \multirow{2}{*}{ Location } & \multicolumn{2}{|c|}{ Geographical Coordinates } & \multirow{2}{*}{$\begin{array}{c}\text { Elevation, } \\
\mathrm{m}\end{array}$} & \multirow{2}{*}{ Time } & \multirow{2}{*}{$\begin{array}{l}\text { Field Intensity, } \\
\qquad \mathrm{dB} \mu \mathrm{V} / \mathrm{m}\end{array}$} & \multicolumn{2}{|c|}{ Quality } & \multirow{2}{*}{$\begin{array}{l}\text { Distancefor } \\
\text { the TX, km }\end{array}$} \\
\hline & & & Latitude-S & Longitude-E & & & & Fixed TV & Mobile TV & \\
\hline 1 & 07-05-13 & Largo da Lac & 849475 & 1314101 & 75 & $9: 30$ & 55,00 & Good & Good & 1 \\
\hline 2 & $"$ & Shoprite & 8505101 & 1316531 & 90 & $10: 30$ & 28,34 & Good & Very Bad & 6,72 \\
\hline 3 & $"$ & Robaldina & 85245 & 131854 & 128 & $11: 10$ & 36,40 & Good & Good & 10,69 \\
\hline 4 & " & Comarca & 853359 & 1321184 & 103 & $11: 30$ & 29,66 & Good & Good & 21,27 \\
\hline 5 & $"$ & Capalanca & 85537 & 1323376 & 154 & $12: 00$ & 27,37 & Very Bad & Very Bad & 21,27 \\
\hline 6 & $"$ & Zango 4 & 94252 & 132546 & 157 & $14: 10$ & 26,35 & No signal & No signal & 35,00 \\
\hline 7 & $"$ & $\mathrm{Km} 30$ & 858138 & 1328263 & 164 & $14: 42$ & 26,37 & No signal & No signal & 31,85 \\
\hline 8 & " & N. Aeoroporto & 900274 & 1331479 & 171 & $15: 22$ & 26,63 & No signal & No signal & 37,2 \\
\hline 9 & $"$ & D. Catete & 93501 & 133608 & 167 & $15: 40$ & 25,77 & No signal & No signal & 49,15 \\
\hline 10 & $"$ & Zango 0 & 858514 & 132338 & 157 & $14: 10$ & 28,08 & Very Bad & Very Bad & 24,76 \\
\hline 11 & $06-05-13$ & Sonangol & 851552 & 1312102 & 21 & $10: 07$ & 59,25 & Good & Good & 10 \\
\hline 12 & $"$ & Morro da Luz & 849148 & 1313384 & 29 & $10: 25$ & 63,30 & Good & Good & 5,4 \\
\hline 13 & $"$ & E. Mussulo & 849146 & 1313386 & 16 & $10: 42$ & 47,18 & Good & Good & 9,1 \\
\hline 14 & " & F. Belas & 854564 & 131022 & 41 & $11: 00$ & 47,05 & Good & Good & 12,47 \\
\hline 15 & $"$ & Praça Benfica & 855524 & 139419 & 21 & $11: 20$ & 46,75 & Good & Good & 14,27 \\
\hline 16 & $"$ & $\mathrm{Km} 30$ & 90269 & 1305104 & 67 & $11: 50$ & 47,10 & Good & Very Bad & 25,83 \\
\hline 17 & $"$ & Ramiros & 93326 & 1302496 & 21 & $12: 20$ & 46,75 & Very Bad & Very Bad & 32,98 \\
\hline 18 & $"$ & Barra Km 50 & 93327 & 132568 & 64 & $12: 50$ & 46,54 & Very Bad & Very Bad & 42,6 \\
\hline 19 & $"$ & Barra Kawza & 91831 & 138138 & 84 & $13: 30$ & 40,25 & No signal & No signal & 54,8 \\
\hline 20 & 09-05-13 & Dimuca & 847587 & 1316296 & 62 & $10: 30$ & 42,31 & Good & Good & 52 \\
\hline
\end{tabular}

\section{CONCLUSION}

1) The evolution of humanity has always been guided by the search for innovations and the improvement of existing techniques. The emergence of Digital TV is another example of a major investment in technological development. Digital Television presents itself as an evolution of analogy television, bringing a great amount of improvements from interactivity, data transmission, improvement in image quality, possibility of transmitting several programs on the same channel, etc.

2) The Japanese system, ISDB, is often presented as an improved version of DVB, as it has many similar features, but with the addition of others. Its main weapons are channel segmentation, which enables and facilitates multiprogramming, as well as the possibility of integrating media such as cell phones and other mobile receivers into its platform.

Angola and other countries, under the guidance of the ITU, should adopt one of the digital television systems by 2015. Our country is taking steps to achieve these goals. Currently, the ISDB system is in experimental issue. This broadcast is still a Study of the implementation of Digital Television in TPA (Luanda, Angola) experimental, but there are already several indications that this system could be adopted by Angola.
3) The switch from analog television to digital television, although advantageous, will present, on the part of users, a series of difficulties, fundamentally financial, to acquire the new digital television receivers, as well as on the part of broadcasters, it will entail costs related to the modification of broadcasting stations. As a solution to minimize the problem on the user's part, there are set-top-boxes with signal outputs for digital receivers and for analog televisions. Angola and other countries, under the guidance of the ITU, should adopt one of the digital television systems by 2015. Our country is taking steps to achieve these goals. Currently, the ISDB system is in experimental issue. This broadcast is still a Study of the implementation of Digital Television in TPA (Luanda - Angola) experimental, but there are already several indications that this system could be adopted by Angola.

4) The change from analog television to digital television, although advantageous, will present, on the part of users, a series of difficulties, fundamentally financial, to acquire the new digital television receivers, as well as on the part of broadcasters, it will entail costs related to the modification of broadcasting stations. As a solution to minimize the problem on the user's part, there are set-top-boxes with signal outputs for digital receivers and for analog televisions. 
5) The study shows that the ISDB-T is a system applicable to our city, as even with the transmitter operating at $50 \%$ of its maximum power, the signal is received in a large part of the city of Luanda, with failures only occurring in very distant regions from the urban center. The implementation of a fully digital transmitter that is foreseen, the increase of the transmitter's power, among other changes, may provide better guarantees of the advantages of implementing the ISDB-T in Angola.

\title{
References
}

1. ITU-R BT.1368-13 (06/2017) Planning Criteria, Including Protection Ratios, for Digital Terrestrial Television Services in the VHF/UHF bands.

2. ITU-R BS.1660-8 (06/2019) Technical Basis for Planning of Terrestrial Digital Sound Broadcasting in the VHF band.

3. ITU-R BS.1116-3 (02/2015) Methods for the Subjective Assessment of Small Impairments in Audio Systems.

4. Kovalgin Y.A., Virgilio S. Current State and Development Trends of Digital Television and Radio Broadcasting in the World. Information and Space. 2017;2:11-24. (in Russ.)

5. DiBEG. ISDB-T Adopting Countries. Available from: https://www.dibeg.org/world/world.html [Accessed 15th July 2021]

6. Bueno E.S., Bedicks G., Akamine C., Horta E.L. Results of Field Tests of the ISDB-T System at $8 \mathrm{MHz}$ in Botswana. Set International Journal of Broadcast Engineering. 2015;1. DOI:10.18580/setijbe.2015.10

7. Akamine C., Iano Y. Simulation Software for the ISDB-T Modulation System. Set International Journal of Broadcast Engineering. 2015;1. DOI:10.18580/setijbe.2015.3

8. Public Finance Information and Communication Technology Service (in Portuguese). Available from: https://setic.minfin.gov. ao/PortalSETIC/\#!/sala-deimprensa/noticias/9103/angola-perspectiva-ter-televisao-digital-terrestre-ate-2023 [Accessed 1st July 2021]

9. Anselmo G. Study of the Implementation of Digital Television at Tpa (Luanda - Angola). Luanda: Agostinho Neto University Publ.; 2013. 141 p. (in Portuguese)

10. ISDBT-T Standards of Botswana. Botswana Communications Regulatory Authority, 2015.

11. ITU-R BT.500-14 (10/2019) Methodologies for the Subjective Assessment of the Quality of Television Images.

12. Report ITU-R BS.2214-5 (10/2020) Planning Parameters for Terrestrial Digital Sound Broadcasting Systems in VHF bands.

13. Innovation, Science and Economic Development Canada. Spectrum Management and Telecommunications Broadcasting Circular. Experimental Operation of In-Band On-Channel (IBOC) Digital Radio in the FM Broadcasting Band. August 2018. Available from: https://www.ic.gc.ca/eic/site/smt-gst.nsf/vwapj/BC-21-I2-EN.pdf/\$file/BC-21-I2-EN.pdf [Accessed 15th July 2021]

14. Russian innovation in the telecommunication sector. Digital terrestrial sound and multimedia broadcasting system for VHF frequency bands RAVIS (Real-time Audio Visual Information System). September 2018. Available from: http://ravisradio.ru/en/materialy/prezentatsii/RAVIS_sept_2018.pdf [Accessed 15th July 2021]

15. NRSC-5-D (04/2017) In-band/on-channel Digital Radio Broadcasting Standard.

16. ITU.R Handbook on Digital Terrestrial Television Broadcasting Networks and Systems Implementation. 2016

\section{$* * *$ \\ Выбор и обоснование цифровой системы телерадиовещания для Республики Ангола}

\author{
В.М.Ж. Сантушш ${ }^{1,2}$ \\ ${ }^{1}$ Министерство телекоммуникаций, информационных технологий связи и коммуникации \\ 2Университет Лузиада, \\ Луанда, Ангола
}

\author{
Информация о статье \\ Поступила в редакцию 16.07.2021 \\ Принята к публикации 22.07.2021
}

Ссылка для цитирования: Сантуш В.М.Ж. Выбор и обоснование цифровой системы телерадиовещания для Республики Ангола // Труды учебных заведений связи. 2021. T. 7. № 3. C. 55-63. DOI:10.31854/1813-324X2021-7-3-55-63

Аннотация: В данной работе рассматривается выбор для Республики Ангола системы телерадиовещания ISDB-T. Обобщены результаты экспериментального цифрового телерадиовещания в формате ISDB-T в Республике Ангола. В настоящее время японская система наземного цифрового телерадиовещания 
(ISDB-T) используется в 14 странах мира, таких как Аргентина, Боливия, Бразилия, Чили, Коста-Рика, Япония, Перу, Парагвай, Сальвадор, Уругвай, Гондурас, Венесуэла, Филиппины, Ботсвана, еще 6 стран, а именно: Ангола, Мальдивы, Шри-Ланка, Гватемала, Эквадор, Никарагуа приняли эту систему. Исследования показывают, что ISDB-Т является системой, применимой в нашей стране, так как даже при работе передатчика на $50 \%$ от его максимальной мощности сигнал принимается в большей части города Луанда, причем с ошибками только в регионах, далеких от центра городской застройки. Увеличение мощности ISDB-T-передатчика, которое предусмотрено, и ряд других изменений может обеспечить уверенный прием программ телерадиовещаня в Республике Ангола. Республика Ангола планирует охватить всю национальную территорию страны цифровым телерадиовещанием, начиная с 2023 года.

Ключевые слова: цифровая передача, система ISDB-T в Республике Ангола, общественное телевидение Анголы.

\section{Список используемых источников}

1. ITU-R BT.1368-13 (06/2017) Planning Criteria, Including Protection Ratios, for Digital Terrestrial Television Services in the VHF/UHF bands.

2. ITU-R BS.1660-8(06/2019) Technical Basis for Planning of Terrestrial Digital Sound Broadcasting in the VHF band.

3. ITU-R BS.1116-3 (02/2015) Methods for the Subjective Assessment of Small Impairments in Audio Systems.

4. Ковалгин Ю.А., Сантуш В.М.Ж.Л. Современное состояние и тенденции развития цифрового телевидения и радиовещания в мире // Информация и космос. 2017. № 2. 11-24.

5. ISDB-T Adopting Countries // DiBEG. URL: https://www.dibeg.org/world/world.html [Accessed 15th July 2021]

6. Bueno E.S., Bedicks G., Akamine C., Horta E.L. Results of Field Tests of the ISDB-T System at $8 \mathrm{MHz}$ in Botswana // Set International Journal of Broadcast Engineering. 2015. Vol. 1. DOI:10.18580/setijbe.2015.10

7. Akamine C., Iano Y. Simulation Software for the ISDB-T Modulation System // Set International Journal of Broadcast Engineering. 2015. Vol. 1. DOI:10.18580/setijbe.2015.3

8. Serviço de Tecnologia de Informação e Comunicação das Finanças Públicas. URL: https://setic.minfin.gov.ao/PortalSETIC/ \#!/sala-deimprensa/noticias/9103/angola-perspectiva-ter-televisao-digital-terrestre-ate-2023 [Accessed 1st July 2021]

9. Anselmo G. Estudo da Implementação da Televisão Digital na Tpa (Luanda - Angola). Luanda: Universidade Agostinho Neto, 2013. $141 \mathrm{p}$.

10. ISDBT-T Standards of Botswana. Botswana Communications Regulatory Authority, 2015.

11. ITU-R BT.500-14(10/2019) Methodologies for the Subjective Assessment of the Quality of Television Images.

12. Report ITU-R BS.2214-5 (10/2020) Planning Parameters for Terrestrial Digital Sound Broadcasting Systems in VHF bands.

13. Spectrum Management and Telecommunications Broadcasting Circular. Experimental Operation of In-Band On-Channel (IBOC) Digital Radio in the FM Broadcasting Band // Innovation, Science and Economic Development Canada. August 2018. URL: https://www.ic.gc.ca/eic/site/smt-gst.nsf/vwapj/BC-21-I2-EN.pdf/\$file/BC-21-I2-EN.pdf [Accessed 15th July 2021]

14. Digital terrestrial sound and multimedia broadcasting system for VHF frequency bands RAVIS (Real-time Audio Visual Information System) // Russian innovation in the telecommunication sector. September 2018. URL: http://ravis-radio.ru/en/ materialy/prezentatsii/RAVIS_sept_2018.pdf [Accessed 15th July 2021]

15. NRSC-5-D (04/2017) In-band/on-channel Digital Radio Broadcasting Standard.

16. ITU.R Handbook on Digital Terrestrial Television Broadcasting Networks and Systems Implementation. 2016

\section{Сведения об авторе:}

САНТУШ Виржилио Матеуш Жоао кандидат технических наук, заместитель начальника отдела космических наук и прикладных исследований Министерства телекоммуникаций, информационных технологий связи и коммуникации Республики Ангола, преподаватель университета Лузиада (Ангола), svirgilio5@gmail.com 